\title{
Review on carbon storage estimation of forest ecosystem and applications in China
}

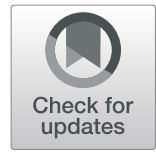

Wanlong Sun and Xuehua Liu*

\begin{abstract}
Background: The accuracy in estimating forest ecosystem carbon storage has drawn extensive attention of researchers in the field of global climate change. However, incomparable data sources and various estimation methods have led to significant differences in the estimation of forest carbon storage at large scales.

Methods: In this study, we reviewed fundamental types of forest carbon storage estimation methods and their applications in China.

Results: Results showed that the major forest carbon storage estimation methods were classified into 3 major categories and 15 subcategories focusing on vegetation carbon storage estimation, soil carbon storage estimation, and litter carbon storage estimation, respectively. The application in China showed that there have been 3 development stages of research in China since the 1990s. Studies of forest carbon storage estimation in province scales were conducted more frequently in the northeastern, eastern and southwestern provinces such as Zhejiang, Heilongjiang and Sichuan with high forest coverage or large forest area. Inventory-based methods, soil type method, and biomass model were the main forest estimation methods used in China, focusing on vegetation, soil and litter carbon storage estimation respectively. Total forest carbon storage of China was approximate $28.90 \mathrm{Pg} \mathrm{C}$, and the average vegetation

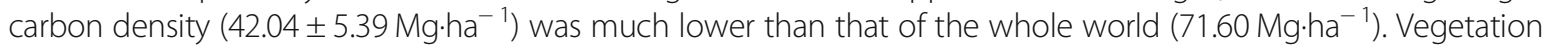
carbon density from average biomass method was the highest $\left(57.07 \mathrm{Mg}^{-h^{-1}}{ }^{-1}\right.$ ) through comparing nine types of vegetation carbon storage estimation methods applied during 1989 to 1993.
\end{abstract}

Conclusions: Many studies on forest carbon storages have been carried out in China at patch scales or regional scales. These efforts enabled the research of forest carbon storage to reach a relatively advanced stage. Meanwhile, the accumulation of massive research data provides the basis for subsequent research work. Some challenges are also existing. This review could provide a reference for more accurate estimation of forest carbon storage in the future.

Keywords: Forest ecosystem, Forest carbon storage estimation, Carbon storage, China

\section{Background}

Forest ecosystem is one of the most important parts of terrestrial ecosystems and the largest carbon pool, occupying an integral position in global carbon cycle of terrestrial ecosystems (Liu et al. 1997; Fang et al. 1998; Wang et al. 2001; Kuuluvainen and Gauthier 2018; Zhao et al. 2019). The world's total forest area was about 4 billion hectares, corresponding to about $31 \%$ of the total land area (FAO 2011, 2016). Over 86\% of the global vegetation carbon pool and over $73 \%$ of the global soil carbon pool are stored in forest ecosystem (Dixon et al.

\footnotetext{
*Correspondence: xuehua-hjx@mail.tsinghua.edu.cn

State Key Joint Laboratory of Environmental Simulation and Pollution Control, and School of Environment, Tsinghua University, Beijing 100084, China
}

1994). Forest ecosystem has higher productivity than any other terrestrial ecosystems, with its fixed carbon accounting for more than two-thirds of the total amount in terrestrial ecosystems each year (Fang et al. 2001a, b). The forest area of China is among the top five globally and covers $20.36 \%$ of the country's total area (FAO 2016). As researched, Chinese forests have served as a carbon sink over the past few decades (Piao et al. 2005a, b; Ju et al. 2007; Fang et al. 2014; Zeng 2014; Zhang et al. 2015), which was primarily due to large-scale afforestation efforts in China, where the forest area increased by 2 million hectares per year in the 1990s and by an average of 3 million hectares per year since 2000 (Fang et al. 2018; Lu et al. 2018). 
Forest ecosystem carbon storage mainly includes forest vegetation carbon storage, soil carbon storage, and litter carbon storage (Lafleur et al. 2018; Lee et al. 2014; Hérault and Piponiot 2018). Accurate estimation of forest ecosystem carbon storage is a major issue that has drawn extensive attention of researches in the field of global climate change. In countries with advanced forestry technologies, such as the United States (Lal 2005; Tian et al. 2015; Domke et al. 2016, 2017), Canada (Liu et al. 1997; Bhatti et al. 2002; Sage et al. 2019), Europe (Neumann et al. 2016; Vanguelova et al. 2016; Rodríguez Martín et al. 2016) and Russia (Warnant et al. 1994; Krankina et al. 1996; Filipchuk et al. 2018), a great deal of research has been conducted on the estimation of forest ecosystem carbon storage. China has also conducted extensive research in this field (Fang et al. 1998; Liu et al. 2000; Fang and Chen 2001; Zhang et al. 2013a; Ji et al. 2016; Liu et al. 2017; Chen et al. 2019) since the 1950s. However, varying data sources, different estimation methods and different scales of study area have led to significant differences in the estimation of forest carbon storage. What's more, given that China comprises several climatic forest types, which could be divided into 7 subtypes based on climatic characteristics (Additional file 1: Table S2). These subtypes of forest ecosystem have different biological and abiotic conditions, responding differently to climate change. In this review, we summarized and analyzed fundamental types of forest carbon storage estimation methods in recent decades, which were classified into 3 major categories and 15 subcategories focusing on vegetation carbon storage estimation, soil carbon storage estimation, and litter carbon storage estimation, respectively. We also reviewed studies focusing on regional carbon storage estimation of forest ecosystem in China in order to discover the development status and research trends in the future. This review could provide references for more accurate estimation of forest carbon storage in China and provide technical support to combat climate change in policies and actions.

\section{Fundamental types of forest carbon storage estimation}

Carbon storage in forest ecosystem mainly includes vegetation carbon storage, soil carbon storage, and litter carbon storage. Estimation of these storages generally used different methods. Estimation methods of forest carbon storage were applied to different forest types in various scales by researchers (Zhang et al. 2005; Wang 2009).

\section{Vegetation carbon storage estimation}

Methods for vegetation carbon storage estimation can be mainly divided into three basic types: (1) inventorybased estimation, (2) satellite-based estimation, and (3) process-based estimation (Piao et al. 2009).

\section{Inventory-based estimation}

Inventory-based estimation is a group of classical study methods of carbon accumulation within forest ecosystems (Fang et al. 1998; Fang and Chen 2001; Jia 2016). These methods were applied to estimate forest carbon storage based on regional forest inventory data, such as forest types, stand age, stand density, stand volume, mean tree height and diameter at breast height $(\mathrm{DBH})$ (Tang et al. 2018). In the past decades, average biomass method, volume-derived method, biomass regression equation and conversion factor continuous method were the four most commonly used methods for estimating vegetation carbon storage based on inventory data (Table 1). These four methods have their own unique advantages and disadvantages. For example, average biomass method tends to overestimate vegetation carbon storage because results based on field measurements are usually greater than the average level in a region or a country (Dixon et al. 1994). The detailed descriptions of these four methods are shown in Table 1.

\section{Satellite-based estimation}

With the application of modern technologies such as Remote Sensing (RS), Geographic Information System (GIS) and Global Positioning System (GPS) at different scales, multi-source remote sensing data have become alternative means of quantifying forest aboveground biomass/carbon storage (Wulder et al. 2012). At present, there are three main types of datasets used for estimating vegetation carbon storage: optical remote sensing data, synthetic aperture radar satellite data (SAR), and Lidar data (LiDAR).

A large number of studies that focused on aboveground biomass inversion using optical remote sensing data have been conducted. The main principle is to construct relationships between band combination and forest stand volume. Hame et al. (1997) constructed empirical relationships of TM3 and TM4 band with forest stand volume based on field sampling data, and applied these empirical relationships to estimate forest carbon storage of northern Finland using AVHRR1 and AVHRR2 bands data. Shaban (2011) took LiDAR and TM remote sensing data to estimate forest stand volume and area in the region of Waldkirch Forest in southwestern Germany. In China, Xing et al. (2004) established regression model between LandSat ETM+ data and biomass of larch forest to estimate the regional forest biomass. Xu et al. (2012) extracted data from QuickBird images in the region of Houbaisha Forest Farm in Fujian Province, and constructed BP artificial neural network to estimate forest biomass. Zhang et al. (2013b) constructed a partial least squares forest stand volume estimation model using topographic, remote sensing and sample environment factors as independent variables based on 
Table 1 Four commonly used methods for estimating vegetation carbon storage based on inventory data

\begin{tabular}{|c|c|c|c|c|}
\hline Methods & Description & Basic formula & Data needed & $\begin{array}{l}\text { Application } \\
\text { Scale }\end{array}$ \\
\hline \multirow[t]{4}{*}{ Inventory-based estimation } & Average biomass method & $Y=A \times y \times d$ & $\begin{array}{l}\text { Average biomass or average carbon density, } \\
\text { carbon content rate, forest area }\end{array}$ & regional \\
\hline & Volume- derived method & $Y=A \times(a \times V+b) \times d$ & Stand volume, forest area, carbon content rate & regional \\
\hline & Biomass regression equation & $Y=A \times a \times\left(D^{b} H\right)^{c} \times d$ & $\begin{array}{l}\text { Diameter at breast height, tree height, forest area, } \\
\text { carbon content rate }\end{array}$ & regional \\
\hline & $\begin{array}{l}\text { Conversion factor continuous } \\
\text { method }\end{array}$ & $\begin{array}{l}\mathrm{BEF}=a+\frac{b}{V} \\
Y=A \times V \times \mathrm{BEF} \times d\end{array}$ & Stand volume, forest area, carbon content rate & regional \\
\hline
\end{tabular}

while $Y$ is vegetation carbon storage, $A$ is the forest area, $y$ is average biomass or average density, $V$ is stand volume, $D$ is diameter at breast height, $H$ is tree height, $d$ is carbon content rate of forest, BEF is biomass expansion factor, which was derived from stand volume, $a, b$, and $c$ are constant changed along with forest types or climatic zones

TM data and compared its accuracy with the results of principal component analysis and multiple stepwise regression. Optical remote sensing is extremely intuitive and sensitive, but the limitations such as limited wavelength range, non-penetrable canopy, or interaction with leaves would affect the inversion results.

Synthetic aperture radar (SAR) has great advantages in estimating forest biomass and storage due to its allweather, all-day, weather-insensitive imaging technology. Toan et al. (1992) estimated forest biomass based on multi-band and multi-polarization AIRSAR. Imhoff (1995) studied radar echo intensity of forests with same biomass level but significantly different structures using MIMICS model and canopy statistics data, resulting in a more in-depth analysis of forest biomass estimation by forest stand structure. SAR has a certain degree of penetrability to forest canopy, the longer the wavelength, the greater the penetration, being able to obtain different canopy depths and forest structure levels data by utilizing different bands or sensors (Nelson et al. 2007). Though with such advantages, SAR signals are largely dependent on terrain and electromagnetic wave wavelengths and are not yet widely applied in China due to technical reasons.

Light detection and ranging (LiDAR) is an active ranging technology. It has the ability to efficiently measure three-dimensional structures, particularly in estimating height and spatial structure of trees. Bortolot and Wynne (2005) estimated regional forest biomass using a regression equation based on identification of single wood using LiDAR technology. Thomas et al. (2006) estimated biomass of mixed forest in northern Ontario, Canada by using different sampling density LiDAR points cloud data. Nelson et al. (2007) improved LiDAR by combining very high frequency radar (VHF-RaDAR) volume scattering. The results showed that the estimation of forest biomass by LiDAR system reached to a fairly high degree of precision. Liu et al. (2013) took Changbai larch forest as the research object in Changbai Mountain Area of Heilongjiang Province. The research used airborne radar point cloud data to identify single wood parameters such as DBH and tree height, and estimated biomass of single wood. LiDAR is able to obtain high-precision vertical structure information of forest, which plays an important role in the extraction of forest structure parameters. However, ice, cloud and land elevation satellite - geoscience laser altimeter system (ICESAT-GLAS) is currently the only spaceborne LiDAR in the world which is owned by National Aeronautics and Space Administration (NASA). It focuses on ice and vegetation in high latitudes with low frequency of revisiting. At present, the most prevalent technology is still airborne laser radar, which is very efficient but expensive.

\section{Process-based estimation}

Process-based estimation could also be divided into two main types: geostatistical modeling and mechanism modeling. Geostatistical modeling combines forest inventory data with topography, elevation, slope, aspect, and other environmental factors to construct statistical models to estimate forest biomass at regional scales using geostatistical methods. Kriging interpolation, K-nearest-neighbours inverse distance interpolation, partial least squares, regression kriging and machine learning are the most commonly used methods for geostatistical models. Destan et al. (2013) studied spatial estimation of forest biomass carbon using spatial interpolation and multi-criteria decision analysis. Shaban (2011) estimated forest volume and basement area of the Waldkirch forest in southwestern Germany using K-near, support vector machine, random forest and artificial neural network, respectively. The results showed that estimation of forest volume by radial-based neural network was more precise than those of other methods. Among them, artificial neural network (ANN) model is widely used for forest biomass estimation (Foody et al. 2001; Cutler et al. 2012; Deng et al. 2014; Zhu and Liu 2015).

Mechanism modeling could be used to quantitatively describe the process of forest carbon cycle and estimate forest carbon storage (Chen 2004). Based on the spatial scales of studies, mechanism modeling methods could be further divided into methods at the patch scale and at the regional scale, respectively (Fig. 1). 


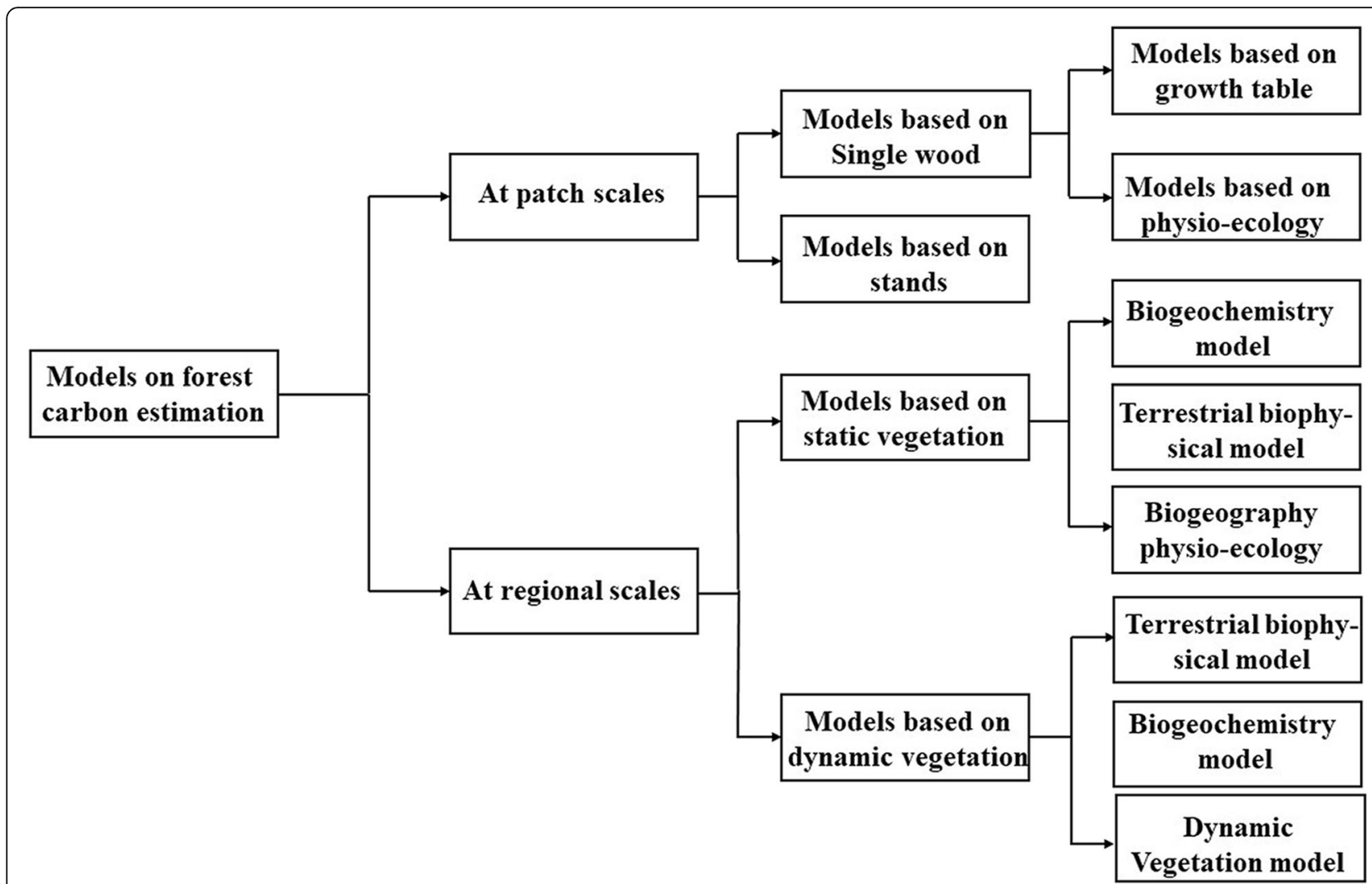

Fig. 1 Types of mechanism models on forest vegetation carbon storage estimation

The methodology of vegetation carbon storage estimation models at the patch scale is designed specifically for forest stands. Initial values and output validation could be obtained through forest inventory. The simulated mechanistic processes first focus on individual organs of a single tree, and then focus on forest stand scale. Models at patch scales simulation are more realistic and the values of vegetation carbon storage are able to achieve higher accuracy through calibration process. However, high quality forest data is required, and this method may not be easily applied to global and even regional carbon storage estimation. The vegetation carbon storage estimation models at the regional scale could be dynamically applied in any region. The time series value could be obtained through remote sensing and other rudimentary methods. Finally, the carbon storage of larger regions and even the global scale could be estimated (Warnant et al. 1994; Bugmann and Solomon 1995; Frolking et al. 1996; Haxeltine and Prentice 1996; Ito and Oikawa 2002; Chen 2004; Lee et al. 2014; Tian et al. 2011, 2015).

\section{Soil carbon storage estimation}

At present, plenty of research has been carried out to estimate soil organic carbon storage. For example, studies have shown that global total soil organic carbon storages may range from 700 to $2946 \mathrm{Pg} \mathrm{C}$ in $100 \mathrm{~cm}$ depth (Jin et al. 2000; O'Rourke et al. 2015), and China takes up 69.1 to 185.7 Pg C (Wang et al. 2004; Yang et al. 2007). Much of this SOC is found in forest ecosystem with the value about $300 \mathrm{Pg} \mathrm{C}$ (Domke et al. 2017), and there was about $20 \mathrm{Pg} \mathrm{C}$ of forest in China (Fang et al. 2018). There are four main methods for estimating soil organic carbon storage.

(1) Soil type method. This method obtains soil carbon organic storage of taxonomic unit based on different soil type sampling data, then calculate regional soil organic carbon storage according to the soil type map. Bohn (1982) estimated global carbon storages at $2200 \mathrm{Pg}$ C. Eswaran et al. (1993) estimated global carbon storage at $1576 \mathrm{Pg} \mathrm{C}$ based on revised soil map of Food and Agriculture Organization (FAO). Batjes (1996) divided the world soil map into 259, 200 basic grid units to calculate average carbon density of the basic grid cells on the basis of soil physicochemical properties and gravel contents, and estimated global soil organic carbon storage to be 1462-1548 Pg C at the depth of $1 \mathrm{~m}$. The Forth Assessment report of 
the Intergovernmental Panel on Climate Change (IPCC 2007) indicated that global forest contains $317 \mathrm{Pg}$ SOC in soils (in the top $30 \mathrm{~cm}$ ). Xie et al. (2004) estimated SOC of $1 \mathrm{~m}$ thickness under different vegetation types in China was 17.3 Pg.

(2) Life belt method. Regional soil organic storage can be calculated by multiplying soil organic carbon density of different life belts or ecosystems with their areas. Post and Mann (1990) subdivided soil density according to geographical distribution, vegetation and climatic factors based on soil data from 2696 soil profiles, and then estimated global soil organic carbon storage at $1395 \mathrm{Pg} \mathrm{C}$.

(3) Soil carbon empirical modeling method. Soil organic carbon was affected by many factors. Therefore, regression relationships could be established among soil organic carbon density and their surrounding environment factors, climatic variables, soil properties, topography to estimate regional forest soil organic carbon storage. The total organic carbon stock of Sichuan forest soil was (2394.26 \pm 514.15$) \mathrm{Tg} \mathrm{C}$, with average carbon density of $190.45{\mathrm{Mg} \cdot \mathrm{ha}^{-1}}^{-1}$, which was estimated by empirical modeling method (Huang et al. 2009).

(4) Process-based modeling method. This approach generally takes soil structure, temperature, water content, and vegetation cover (for turnover rate calculation) into consideration, and divides soil into different carbon pools to simulate the process of soil carbon cycle according to decomposition rate. RothC, SOMM, Yasso, CENTURY, and ROMUL are the typical representation of such models (Xu et al. 2018). Han (2012) used RothC to stimulate soil carbon dynamic of forest in the Qinling Mountains, the results showed that $68.66 \mathrm{Tg} \mathrm{C}$ would be fixed during 2000-2020.

\section{Litter carbon storage estimation}

Litter accounts for only $5 \%$ of the total carbon storage of forest ecosystem, but it is an indispensable part of carbon pool, as well as an important part of material circulation of forest ecosystem. It is also the link between vegetation carbon pool and soil carbon pool (Pan et al. 2011). Carbon storage of litter could be calculated by multiplying existing amount of litter and carbon content of litter. There are two widely applied methods.

(1) Biomass modeling method. This method constructs relationship between litter and aboveground biomass. Then the amount of litter could be calculated with known aboveground biomass. On the basis of known carbon content of litter, carbon storage of litter can be estimated (Domke et al. 2016).
(2) Process-based modeling method. These models take decomposition process of litter into consideration. Carbon storage of litter is estimated by calculating the decomposition and turnover rate of organic carbon in the litter layer. At present, several representative models have been established, such as RothC, SOMM, Yasso, CENTURY, and ROMUL (Xu 2014).

\section{Studies on forest carbon storages in China}

In the database of "Web of Science", we searched keywords which relate to the subject by different levels. The main keywords were "forest or forest ecosystem", "China", "carbon storage", and "carbon stock". In total, 2761 studies related to forest carbon storage in China published between 1991 and 2018 were found by searching different combinations of the keywords.

\section{Research stages on forest carbon storages in China}

In terms of the numbers of related research publications, there have been 3 development stages of research in China since the 1990s (Fig. 2): the beginning stage (1991-2000), the popularization stage (2001-2012), and the acceleration stage (2013-now).

As noted, the research on forest carbon storage started relatively late in China. There were only 26 studies published from 1991 to 2000 were found. Methods used during this beginning stage were largely introduced from abroad. These efforts became the basic framework for the subsequent popularization and acceleration stages.

During 2001-2012, global climate change was payed high attention. The number of studies focusing on forest carbon storage in China reached to 895, which was approximately 34.5 times the number of studies in the beginning stage. In the current stage (2013-now), the number of published studies has reached to 1840, which is much higher than that of the popularization stage. This pattern indicates that estimation of forest carbon storage has become a popular research field in China. In these two stages, methodologies of estimating forest carbon storage improved gradually. The modern technologies started to be widely used, such as SAR and LiDAR. These improvements significantly improved the accuracy of forest carbon storage estimation.

\section{Distribution of research areas in China}

In order to review regional research status in China, 485 research publications on regional (taking a province as the regional scale, excluding Hong Kong, Macao and Taiwan) estimation of forest carbon storage in China were selected for quantitative analysis. Each province has conducted the research on estimation of forest carbon storage at different research frequencies (Fig. 3). There were more studies conducted in the northeastern, 


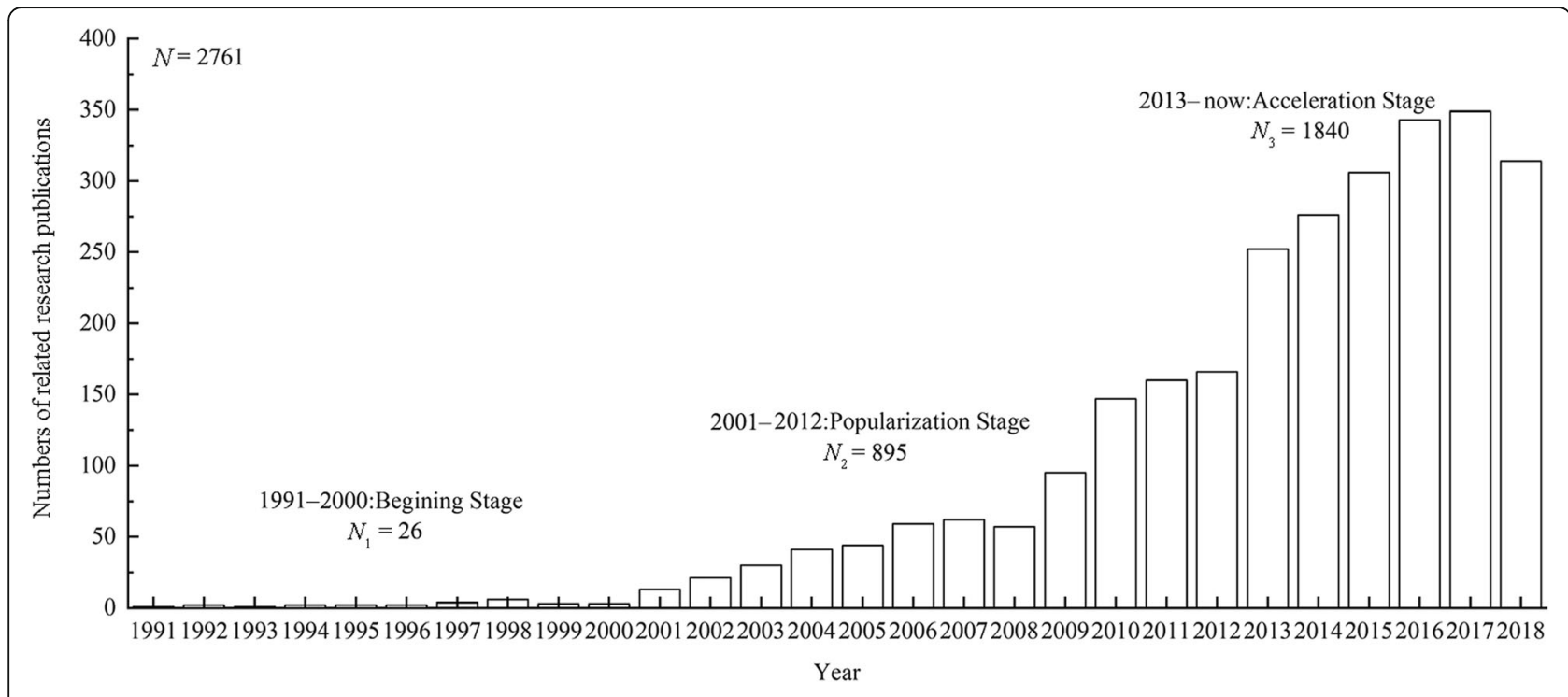

Fig. 2 Development stages of forest carbon estimation in China

eastern and southwestern provinces. Zhejiang ranked first with 39 studies, followed by Heilongjiang with 38 studies and Sichuan with 32 studies.

In this review, we analyzed the correlation between research frequencies with forest coverage, forest area and GDP of each province. Correlation analysis showed that research frequencies were significantly positively correlated with forest coverage $(p=0.0003)$ and forest area $(p=$ 0.002). GDP also had correlation with research frequencies, but not significant $(p=0.06)$ (Table 2). This correlation analysis may partly explain why higher frequencies of research on forest carbon storage occurred in the northeastern, eastern and southwestern provinces with high forest coverage or large forest area.

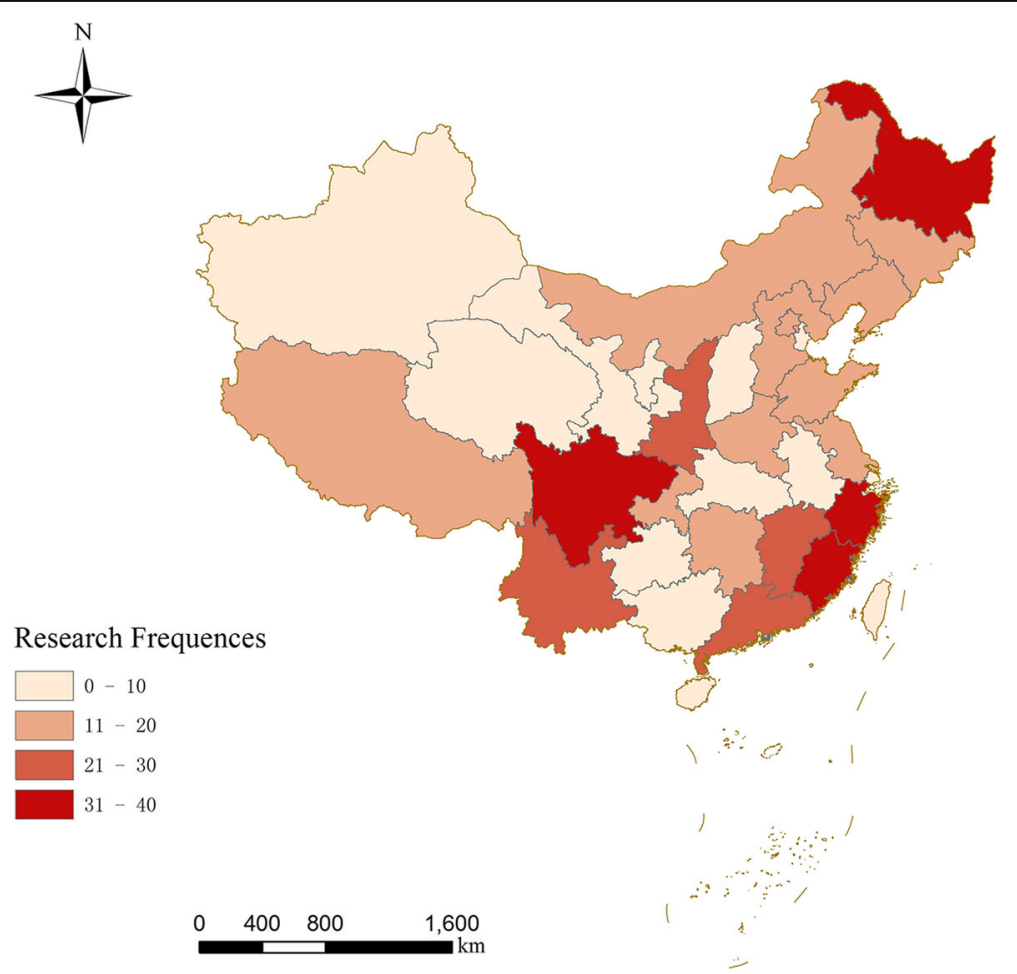

Fig. 3 Distribution pattern of research frequencies in China 
Table 2 Influencing factors resulting regional research frequencies and their relationship $(n=31)$

\begin{tabular}{lllll}
\hline & Research frequency & Coverage & Forest area & GDP \\
\hline Research frequency & 1.00 & & & \\
Coverage & $0.60^{* *}$ & 1.00 & & \\
Forest area & $0.53^{* *}$ & 0.31 & 1.00 & \\
GDP & 0.34 & 0.15 & -0.15 & 1.00 \\
\hline
\end{tabular}

Notes: ${ }^{* *} p<0.01$

\section{Research methods used in China}

In order to analyze research methods used on estimation of forest carbon storage, 500 publications were reviewed. Methods used were divided into 15 types. Inventory-based methods were used 249 times for vegetation carbon estimation (Fig. 4). Among inventory-based methods, volume derived method (V2) and conversion factor continuous method (V4) were adopted mostly. Numbers of satellitebased methods used increased to 65 times, while ORS (V5) was used 58 times. SAR (V6) and LiDAR (V7) need to be applied further. There were also many studies used process-based methods to estimate vegetation carbon in China, including geostatistical models (V8, 21 times) and process-based models (V9, 36 times).

In terms of soil carbon estimation, four main methods were adopted by researchers for 93 times in our review (Fig. 4). Soil type method (S1) was adopted 79 times, which occupied $84.95 \%$ of all methods used. The other three methods (S2, S3, S4) were adopted relatively fewer. Studies of litter carbon estimation were significant less than those of vegetation and soil carbon estimation. In our review, only two types of litter carbon estimation methods were found, and totally be used 31 times. Biomass model was more commonly adopted to estimate litter carbon storage (Fig. 5).

\section{Carbon storage estimation of forest ecosystem in China} Total carbon storage of forest ecosystem in China was calculated in previous work. Vegetation-C, Soil-C (0$100 \mathrm{~cm}$ soil layer), and litter-C storage were estimated at $8.65 \pm 1.52$ (after 2007), 21.16 \pm 5.39 , and $0.86 \pm 0.08 \mathrm{Pg}$ $\mathrm{C}$, respectively, with an approximately sum of $28.90 \mathrm{Pg}$ $\mathrm{C}$ storage in Chinese forest ecosystem. The average densities of vegetation-C, Soil-C (0-100 cm soil layer), and litter-C storage were approximately $43.11 \pm 10.42$,

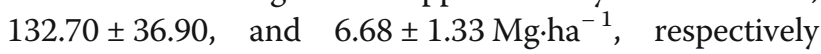
(Additional file 1: Table S1).

Figure 5 showed the temporal pattern of forest storage and carbon density of vegetation-C. The temporal pattern could be divided into two stages. In the first stage, carbon storage of vegetation decreased from 5.06 Pg C (1949) to $4.10 \pm 0.56 \mathrm{Pg} \mathrm{C}(1973-1976)$, and then increased to $9.65 \pm 0.60 \mathrm{Pg} \mathrm{C}$ (2009-2013). Carbon density of vegetation changed between $35.50 \pm 5.65 \mathrm{Mg} \cdot \mathrm{ha}^{-1}$
(1984-1988) and $50.71 \pm 5.65 \mathrm{Mg} \cdot \mathrm{ha}^{-1} \quad$ (2009-2013), with an average value of $42.04 \pm 5.39 \mathrm{Mg} \cdot \mathrm{ha}^{-1}$, which was much lower than that of the whole world (71.60 $\mathrm{Mg} \cdot \mathrm{ha}^{-1}$ ) (Sun et al. 2016).

In order to compare the differences between vegetation carbon estimation methods, studies which were conducted between 1989 and 1993 were selected (for the data were comparable over the same time period). A total of 13 studies focusing on forest vegetation carbon storage in China were reviewed. Among the selected studies, 4 types of inventory-based methods and 3 mechanism models were used to estimate forest vegetation carbon storage (Table 3). However, there was no satellite-based method used to estimate whole forest vegetation carbon storage during this period. Estimated carbon densities varied due to different estimation methods. Carbon densities estimated from BIOME3 and CEVSA model were much higher than those from CASA model and inventory-based methods. In terms of inventory-based estimation, average carbon density from average biomass method was the highest (57.07 Mg.ha- ${ }^{-1}$ ), followed by that from conversion factor continuous method $\left(39.99 \pm 3.66 \mathrm{Mg} \mathrm{ha}^{-1}\right)$, biomass

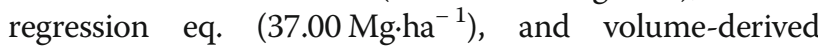

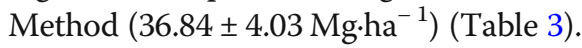

\section{Research trends}

These quantitative statistics confirm the obviously increasing trends in forest ecosystem carbon storage research in China. Throughout the three stages of development in China, we can see a notable shift toward increasing academic practitioners and research methods. These produce lots of different types of dataset. Based on the massive data, we need furthermore quantitative studies to obtain more accurate estimation results.

(1) More up to date and effective forest survey data are needed. Forest inventory data are recognized as the most reliable sources of data for global carbon cycle research (Smith et al. 2002). In our review, differences in datasets appear to be the main factors on explaining variation in the forest carbon storage. Most previous studies at national scale used national inventory data (once every 5 years since 1973) and remote sensing data to estimate vegetation-C storage, and used Second National Soil Survey (1979-1985) data to calculate soil-C storage (Yu et al. 2010; Xu et al. 2018). Litter-C storage was estimated based on vegetation biomass data obtained from national forest inventory data (Wen and He 2016; Zhu et al. 2017). These data have certain time delay, and several sources of errors that may cause uncertainties in carbon stocks estimates were existed, such as, the definitions of tree components (stem, branch, leaf, root may varied in 


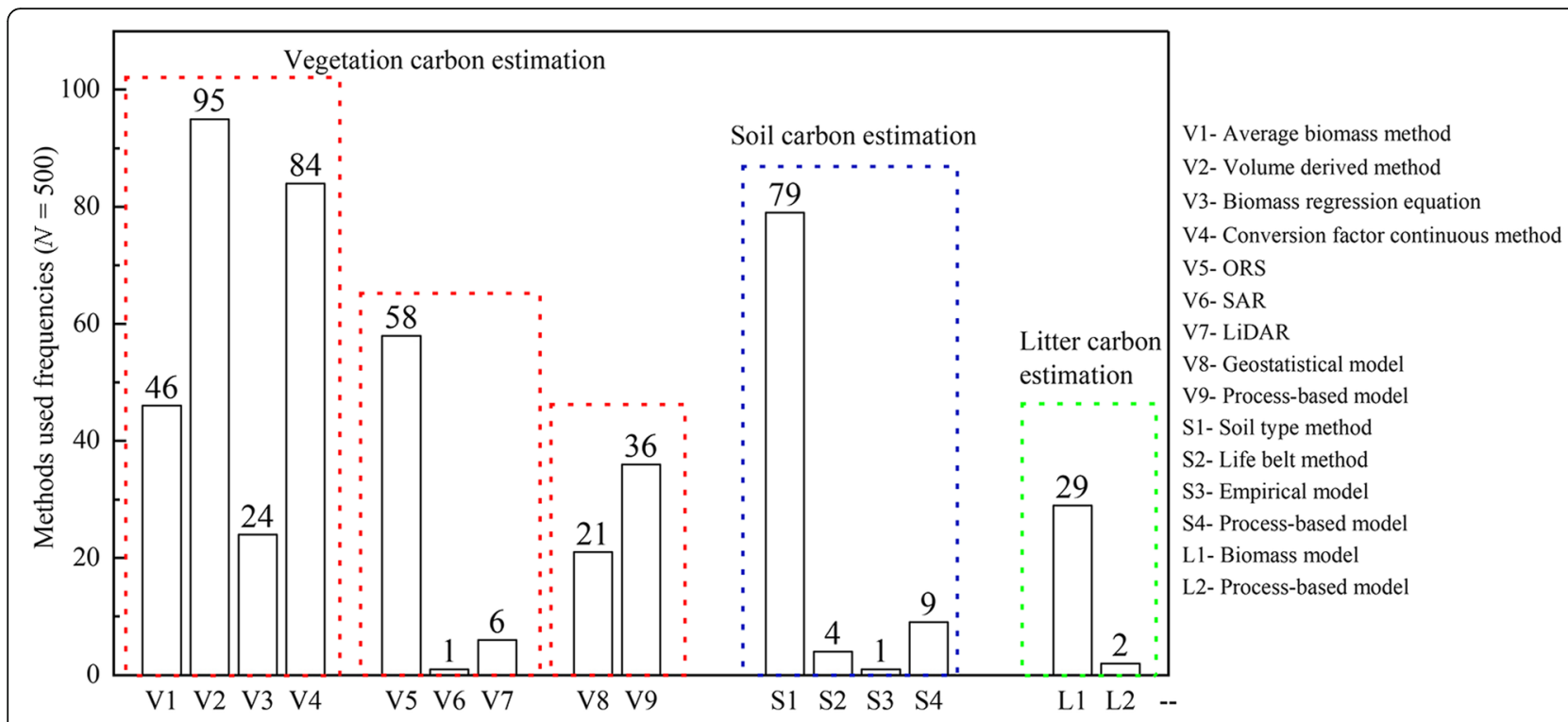

Fig. 4 Frequencies of research methods used in China

different samplings), the variations in inventory methods, no distinction between forest types, and the relatively small amount of sample data (forest area and timber volume) (Pan et al. 2004). Thus, recent and comprehensive data would be needed in order to facilitate more accurate estimations, and intensive field survey is needed (Tang et al. 2018). Network of long-term, largescale field experiments are needed to reduce scaling uncertainty, for example, different sampling times may lead to uncertainties in estimation accuracy. Thus, sampling time also needs to be taken into consideration, in parallel with improving the precision of carbon estimation by developing observation techniques, increasing observation frequencies and parameters.

(2) Mechanism process and control factors of forest carbon cycle needed advanced research. The forest carbon stock not only influenced by forest growth but also by conditional factors (such as geographical condition, regional temperature, precipitation, nitrogen deposition, microbial activity) (Liu et al. 2012). These conditional factors formed different forest types, contributing to forest carbon stock

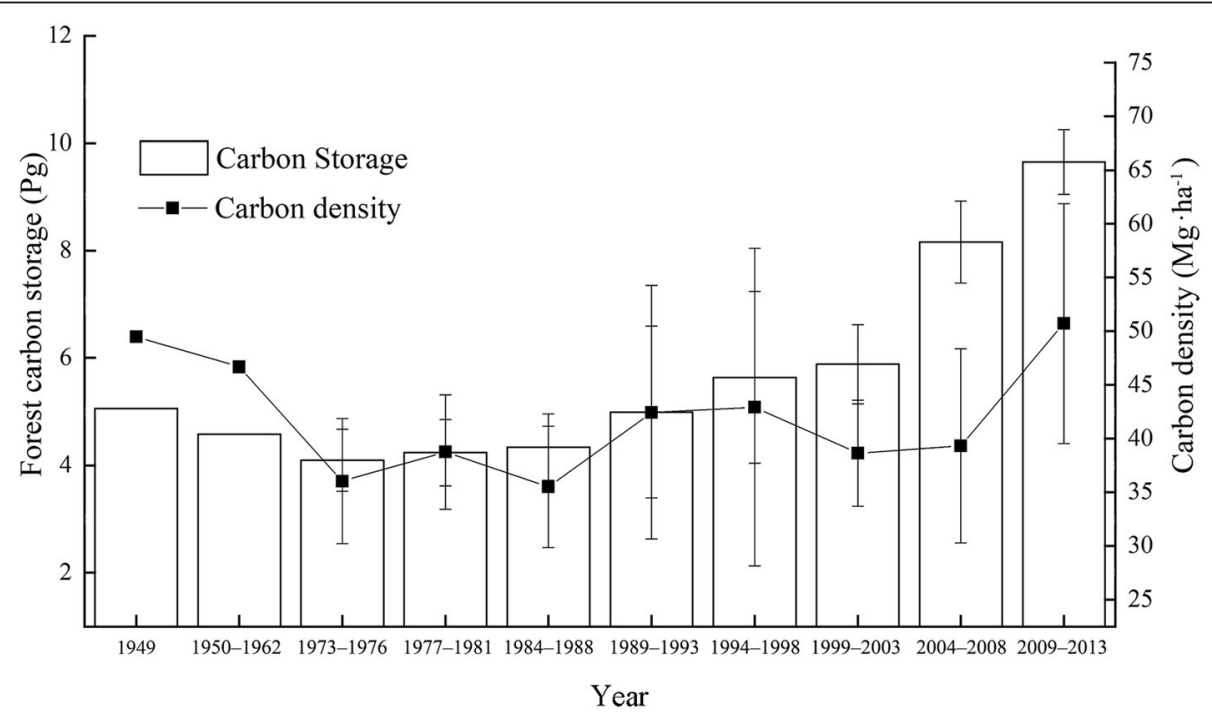

Fig. 5 Temporal pattern of forest carbon storage and carbon density of Vegetation-C in China 
Table 3 Research on forest vegetation carbon storage in China during 1989-1993

\begin{tabular}{|c|c|c|c|c|}
\hline Estimation Methods & $\begin{array}{l}\text { Forest area } \\
\left(10^{4} \mathrm{~km}^{2}\right)\end{array}$ & $\begin{array}{l}\text { Carbon density } \\
\left(\mathrm{Mg}^{\prime} \mathrm{ha}^{-1}\right)\end{array}$ & $\begin{array}{l}\text { Carbon storage } \\
(\mathrm{Pg} \mathrm{C})\end{array}$ & Reference \\
\hline Volume-derived method & 108.64 & 38.70 & 4.20 & (Liu et al. 2000) \\
\hline Volume-derived method & 108.63 & 34.29 & 3.73 & (Wang et al. 2001) \\
\hline Volume-derived method & 91.43 & 41.32 & 3.78 & (Zhao and Zhou 2004) \\
\hline Volume-derived method & 108.64 & 37.87 & 4.11 & (Xu et al. 2007) \\
\hline Volume-derived method & 108.64 & 38.85 & 4.22 & (Wu et al. 2008) \\
\hline Volume-derived method & 199.78 & 30.04 & 6.00 & (Zhang et al. 2013a) \\
\hline Average biomass method & 108.62 & 57.07 & 6.20 & (Zhou et al. 2000) \\
\hline Biomass regression equation & 108.6 & 37.00 & 4.02 & (Pan et al. 2004) \\
\hline Conversion factor continuous method & 108.63 & 42.58 & 4.63 & (Fang et al. 2001b) \\
\hline Conversion factor continuous method & 131.8 & 37.40 & 4.93 & (Fang et al. 2007) \\
\hline BIOME3 & 127.06 & 71.70 & 9.11 & (Nan 2001) \\
\hline CEVSA & 121.63 & 71.69 & 8.72 & (Li et al. 2003) \\
\hline CASA Model & 127.89 & 45.30 & 5.79 & (Piao et al. 2005a, b) \\
\hline
\end{tabular}

estimation (Asner et al. 2009; Barbosa et al. 2014). For forest biomass carbon estimation, forest types and tree species have great impacts on carbon estimates (Neumann et al. 2016), the highest biomass of mature forests occurred mainly in the mid-latitude regions where mean annual temperatures were $8-10^{\circ} \mathrm{C}$ and mean annual precipitation was between 1000 and $2500 \mathrm{~mm}$ (Liu et al. 2014). Here it is also important to know the definition of the various tree compartments of different tree species as this also affects the results (Jenkins et al. 2003). What's more, carbon is derived by multiplying biomass with the carbon fraction, which differed by ecoregion (Thomas and Martin 2012), tree species (Lamlom and Savidge 2003), tree compartment (Lamlom and Savidge 2006; Poorter et al. 2012), ages (Köhl et al. 2017), or by locations (Ma et al. 2018). For soil organic carbon and litter carbon estimation, total C of soils significantly increased with altitude (Tashi et al. 2016), given the key processes of SOC are temperature-dependent. Root respiration and microbial decomposition are also subject to water limitation (Davidson and Janssens 2006). In order to improve SOC and litter carbon estimates, surveys are needed to carried out per biome, climatic zone, vegetation group, soil group with routinely measured in inventories like stem volume. Therefore, the relationship between forest carbon estimation and environmental condition indicates the need to study the varying patterns of those climatic variables in certain places.

What's more, nutrient availability will be also need to take into consideration to evaluate its impacts on forest productivity and stocks, for terrestrial carbon storage is dependent on the availability of nitrogen for plant growth (Wieder et al. 2015). And management activities such as thinning or harvesting which could decrease the SOC content should also to be considered (Jandl et al. 2007).

(3) Forest carbon storage estimation methods need to be more comprehensive and accurate. Part of uncertainties in forest carbon storage estimates may be caused by environmental drivers while the rest is an effect of the estimation methodology (Jenkins et al. 2003). Differences in the methods may partially contribute to the large uncertainty of carbon storage estimation at large scales (Xu et al. 2018). Most previous studies calculated vegetation$\mathrm{C}$ storage, soil-C storage, and litter-C storage based on ecosystem type, vegetation type, or soil type, respectively (Zhang et al. 2013a; Yang et al. 2014). In the future, studies should incorporate data of climate, vegetation and land use to improve the estimation methods. Large scales should be divided into small plaques with their own characteristics in order to generate more accurate estimation. Furthermore, different key parameters selected for evaluation (e.g. plant $C$ content, soil bulk density, soil depth, and areas) may also cause large uncertainties in carbon storage estimation (Yang et al. 2011). With the growth of the technologies, the integration of LiDAR and VHR satellite imaging is a good combination for better biomass mapping with spatial accuracy. With the availability of various scales of remote sensing imagery, from coarser to higher resolution, integration of this multisensory technology could improve the estimation from local to regional scales' estimation (Baccini et al. 2012). The development of modelling regression to acquire the best estimation of forest carbon storage would be a new direction, especially 
after the breakthrough in the field of deep learning. Some convolutional neural network algorithm (CNN) may have potential for estimating forest carbon stocks combine with remote sensing images, such as Alex (Hafemann et al. 2014). From the modeling perspective, divergent model estimates of carbon dynamics informed us of cautiously interpreting current model and its feedback to climate system. How to improve and validate model performance in simulating long-term forest carbon dynamics is a bigger challenge, which should be employ biogeochemical processes, including photosynthesis, absorption, and carbon allocation into the models.

(4) The effect and feedback of climate change on forest carbon stocks could be considered seriously. The carbon density of the forests, exhibited a strong correlation with climate, it decreased with increasing temperature but increased with increasing precipitation. SOC is sensitive to global change effects, particularly climate (Tian et al. 2015). Another uncertainty derived from the climate change is soil respiration, which has been extensively studied through field experiments, laboratory incubations, and ecosystem modeling. Rising atmospheric $\mathrm{CO}_{2}$ is expected to stimulate plant growth and soil $\mathrm{C}$ input but may also alter microbial decomposition. The combined effect of these responses on long-term $\mathrm{C}$ storage is unclear, climate change can both increase NPP in some regions or decrease it in other regions (Van Groenigen et al. 2014). How optimally competitive tree allocation should change in response to elevated atmospheric $\mathrm{CO}_{2}$ along a gradient of nitrogen and light availability, together with how those changes should affect carbon storage in living biomass need to be investigated.

(5) Forest carbon storage estimation in China needs to consider more about forest status and development trends. Wood density is strongly correlated to tree ring width (MacPeak et al. 1990; Repola 2006; Ledermann and Neumann 2006) but also to tree age. It is well known that constant biomass expansion factors tend to overestimate biomass for young trees and underestimate biomass for older trees (Pietsch and Hasenauer 2002). More than 80\% of the forests in China belong to immature forests with young and poor quality secondary forests, which were the main reasons for the low carbon storage and carbon density of forests in China (Liu et al. 2000; Zhao and Zhou 2004). The higher carbon estimation obtained along with time may be due to the implementation of key ecological restoration projects (e.g. Three-North Shelter
Forest Program 4th Phase, Yangtze River Shelter Forest Project and Zhujiang River Shelter Forest Project 2nd Phase, Natural Forest Protection Project, etc.). These ecological restoration projects have contributed to carbon sequestration in the vegetation and soil in recent decades. In addition, China comprises several climatic forest types, which would response to climate change in different extents, more attention should be payed to the effects of climate change on varied climatic forest types.

\section{Conclusion and suggestion}

China is a mountainous country with a vast territory and complex terrain, as well as comprises several climatic zones including cold, temperate, subtropics and tropics. The diversities of terrestrial ecosystems under different climate zones and land-use changes are very complicated. Various factors such as vegetation type and productivity, temperature, soil moisture, soil properties and nutrient, and disturbance regimes varied with climate change can affect the dynamic of forest carbon. As the most important part of terrestrial ecosystems, many studies on forest carbon storages have been carried out in China at patch scales or regional scales. These efforts enabled the research of forest carbon storage to reach a relatively advanced stage. Meanwhile, the accumulation of massive research data provides the basis for subsequent research work. Some challenges are also existing. One of the major uncertainties is forest inventory data of China were not comprehensive enough and detailed. The lack of dynamic monitoring data, economic forest, shrub layer and underground biomass data resulted in inaccurate estimation of forest carbon storage. Another uncertainty is derived from the climate sensitivity and differences in divergent carbon estimation models. To address nutrient limitation that affects NPP, biomass formation, litterfall, and SOC decomposition is of critical significance for accurately estimating carbon stocks as well as future projections. Therefore, in order to improve estimation accuracy of forest carbon storage, (1) long-term follow-up observation of forest ecosystem changes is necessary, (2) basic information of forest resources should be constantly enriched and updated so as to improve the precision of inventory sampling, (3) estimation methods should be refined and unified continuously, models ought to have better representation of the estimation of initial NPP, litter composition, decay, and net nitrogen mineralization by comparing model performance against site level observations, and (4) the integration of multisensory technologies such as deep learning algorithm and remote sensing may be a new meaningful direction. 


\section{Supplementary information}

Supplementary information accompanies this paper at https://doi.org/10. 1186/s40663-019-0210-2

Additional file 1: Table S1. Carbon density and storage of forest ecosystem in the scale of whole China, which obtained from published researches from 1980s to now. Table S2.

\section{Abbreviations}

AIRSAR: Air radar satellite; BEF: Biomass expansion factor; DBH: Diameter at breast height; GIS: Geographic information system; GPS: Global positioning system; ICESAT-GLAS: Ice, cloud and land elevation satellite - geoscience laser altimeter system; LiDAR: Lidar data; MIMICS: Microbial-mineral carbon stabilization; NASA: National aeronautics and space administration; NPP: Net primary production; RS: Remote sensing; SAR: Radar satellite data; VHFRaDAR: Very high frequency radar

\section{Acknowledgements}

We express our great thanks to Fandi Shen for her meaningful working on linguistic modification.

\section{Authors' contributions}

WS planned the project, undertook most of the literature review, and wrote the review. XL contributed additional literature and contributed substantially to modify the manuscript. Both authors read and approved the final manuscript.

\section{Funding}

National Natural Science Foundation of China (NSFC projects: No. 41271194 and No. 41671183).

\section{Availability of data and materials}

Not applicable.

\section{Ethics approval and consent to participate}

Not applicable.

\section{Consent for publication}

Not applicable.

\section{Competing interests}

The authors declare that they have no competing interests.

Received: 5 June 2019 Accepted: 14 November 2019

Published online: 30 November 2019

\section{References}

Asner GP, Flint Hughes R, Varga TA, Knapp DE, Kennedy-Bowdoin T (2009) Environmental and biotic controls over aboveground biomass throughout a tropical rain forest. Ecosystems 12:261-278. https://doi.org/10.1007/s10021008-9221-5

Baccini A, Goetz SJ, Walker WS, Laporte NT, Sun M, Sulla-Menashe D, Hackler J, Beck PSA, Dubayah R, Friedl MA, Samanta S, Houghton RA (2012) Estimated carbon dioxide emissions from tropical deforestation improved by carbon-density maps. Nat Clim Chang 2:182-185. https://doi.org/10.1038/nclimate1354

Barbosa JM, Broadbent EN, Bitencourt MD (2014) Remote sensing of aboveground biomass in tropical secondary forests: a review. Int J Forestry Res 2014:715796. https://doi.org/10.1155/2014/715796

Batjes NH (1996) Total carbon and nitrogen in the soils of the world. Eur J Soil Sci 47:151-163. https://doi.org/10.1111/j.1365-2389.1996.tb01386.x

Bhatti J, Apps M, Jiang H (2002) Influence of nutrients, disturbances and site conditions on carbon stocks along a boreal forest transect in central Canada. Plant Soil 242:1-14. https://doi.org/10.1023/A:1019670619316

Bohn HL (1982) Estimate of organic carbon in world soils: II. Soil Sci Soc Am J 46: 1118-1119. https://doi.org/10.2136/sssaj1982.03615995004600050050x

Bortolot ZJ, Wynne RH (2005) Estimating forest biomass using small footprint LiDAR data: an individual tree-based approach that incorporates training data. ISPRS Photogramm 59:342-360. https://doi.org/10.1016/j.isprsjprs.2005.07.001

Bugmann HKM, Solomon AM (1995) The use of a European forest model in North America: a study of ecosystem response to climate gradients. J Biogeogr 1:477-484. https://doi.org/10.2307/2845944
Chen BQ (2004) Earth system carbon cycle. Science Press, Beijing (in Chinese)

Chen Y, Cao J, Zhou L, Li F, Fu S (2019) Effects of prescribed burning on carbon accumulation in two paired vegetation sites in subtropical China. For Ecosyst 6:26. https://doi.org/10.1186/s40663-019-0185-z

Cutler MEJ, Boyd DS, Foody GM, Vetrivel A (2012) Estimating tropical forest biomass with a combination of SAR image texture and landsat TM data: an assessment of predictions between regions. ISPRS J Photogramm 70:66-77. https://doi.org/10.1016/j.isprsjprs.2012.03.011

Davidson EA, Janssens IA (2006) Temperature sensitivity of soil carbon decomposition and feedbacks to climate change. Nature 440:165-173. https://doi.org/10.1038/nature04514

Deng S, Katoh M, Guan Q, Yin N, Li M (2014) Estimating forest aboveground biomass by combining ALOS PALSAR and WorldView-2 Data: a case study at Purple Mountain National Park, Nanjing, China. Remote Sens 6(9):7878-7910. https://doi.org/10.3390/rs6097878

Destan S, Yilmaz O, Sahin A (2013) Making objective forest stand maps of mixed managed forest with spatial interpolation and multi-criteria decision analysis. iForest 6:268-277. https://doi.org/10.3832/ifor0099-006

Dixon RK, Brown S, Houghton RA, Solomon AM, Trexler MC, Wisniewski J (1994) Carbon pool and flux of global forest ecosystems. Science 263:185-190. https://doi.org/10.1126/science.263.5144.185

Domke GM, Perry CH, Walters BF, Nave LE, Woodall CW, Swanston CW (2017) Toward inventory-based estimates of soil organic carbon in forests of the United States. Ecol Appl 27:1223-1235. https://doi.org/10.1002/eap.1516

Domke GM, Perry CH, Walters BF, Woodall CW, Russell MB, Smith JE (2016) Estimating litter carbon stocks on forest land in the United States. Sci Total Environ 557-558:469-478. https://doi.org/10.1016/j.scitotenv.2016.03.090

Eswaran H, Berg EVD, Reich P (1993) Organic carbon in soils of the world. Soil Sci Soc Am J 57:192-194. https://doi.org/10.2136/sssaj1993. $03615995005700010034 x$

Fang JY, Chen AP (2001) Dynamic forest biomass carbon pools in China and their significance. Acta Bot Sin 43:967-973 (in Chinese with English abstract)

Fang JY, Chen AP, Peng C, Zhao S, Ci L (2001b) Changes in forest biomass carbon storage in China between 1949 and 1998. Science 292:2320-2323. https://doi.org/10.1126/science.1058629

Fang JY, Chen AP, Peng CH, Zhao SQ, Ci LJ (2001a) Changes in forest biomass carbon storage in China between 1949 and 1998. Science 292:2320-2322. https://doi.org/10.1023/A:101072860

Fang JY, Guo ZD, Hu HF, Kato T, Muraoka H, Son Y (2014) Forest biomass carbon sinks in east Asia, with special reference to the relative contributions of forest expansion and forest growth. Glob Chang Biol 20(6):2019-2030. https://doi. org/10.1111/gcb.12512

Fang JY, Guo ZD, Piao SL, Chen AP (2007) Estimation of carbon sequestration of terrestrial vegetation in China from 1981 to 2000. Chin Sci S D: Earth Sci 37 804-812

Fang JY, Liu GH, Xu SL (1996) Biomass and net production of forest vegetation in China. Acta Ecol Sin 16:497-508 (in Chinese with English abstract)

Fang JY, Wang GG, Liu GH, Xu SL (1998) Forest biomass of China: an estimate based on the biomass-volume relationship. Ecol Appl 8:1084. https://doi.org/ 10.1890/1051-0761(1998)008[1084:FBOCAE]2.0.CO;2

Fang JY, Yu GR, Liu LL, Hu SJ, Chapin FS (2018) Climate change, human impacts, and carbon sequestration in China. PNAS 115(16):4015-4020. https://doi.org/ 10.1073/pnas.1700304115

FAO (2011) State of the world's forests 2011, Rome, p 179

FAO (2016) Global forest resources assessment 2015-how are the world's forests changing? 2nd edn, Rome, p 54

Filipchuk A, Moiseev B, Malysheva N, Strakhov V (2018) Russian forests: a new approach to the assessment of carbon stocks and sequestration capacity. Environ Dev 26:68-75. https://doi.org/10.1016/j.envdev.2018.03.002

Foody GM, Cutler ME, McMorrow J, Pelz D, Tangki H, Boyd DS, Douglas IAN (2001) Mapping the biomass of Bornean tropical rain forest from remotely sensed data. Glob Ecol Biogeogr 10:379-387. https://doi.org/10.1046/j.1466822X.2001.00248.X

Frolking S, Goulden ML, Wofsy SC (1996) Modelling temporal variablility in the carbon balance of a spruce/moss boreal forest. Glob Chang Biol 2:343-366 https://doi.org/10.1111/j.1365-2486.1996.tb00086.x

Hafemann LG, Oliveira LS, Cavalin P (2014) Forest species recognition using deep convolutional neural networks. In: 2014 22nd International Conference on Pattern Recognition. IEEE, Stockholm, pp 1103-1107. https:/doi.org/10.1109/ICPR.2014.199

Hame T, Salli A, Andersson K, Lohi A (1997) A new methodology for the estimation of biomass of conifer dominated boreal forest using NOAA 
AVHRR data. Int J Remote Sens 18:3211-3243. https://doi.org/10.1080/ 014311697217053

Han QS (2012) Studying the dynamic of the soil organic carbon of main forest types in Qinling Mountains in Shaanxi Province with RothC model. Master. Northwest Agriculture \& Forestry University. https://doi.org/10.1029/ 96GB02344 (in Chinese with English abstract)

Haxeltine A, Prentice IC (1996) BIOME3: an equilibrium terrestrial biosphere model based on ecophysiological constrains, resource availablity, and competition among plant functional types. Global Biogeochem Cy 10:693709. https://doi.org/10.1029/96GB02344

Hérault B, Piponiot C (2018) Key drivers of ecosystem recovery after disturbance in a neotropical forest. For Ecosyst 5:2. https://doi.org/10.1186/540663-017-0126-7

Huang CD, Zhang J, Yang WQ, Zhang GQ, Wang YJ (2009) Spatial distribution characteristics of forest soil organic carbon stock in Sichuan Province. Acta Ecol Sin 29:1217-1225 (in Chinese with English abstract)

Imhoff M (1995) Radar backscatter and biomass saturation: ramifications for global biomass inventory. IEEE T Geosci Remote 33:511-518

Ito A, Oikawa T (2002) A simulation model of the carbon cycle in land ecossytems (Sim-cycel): a description based dry matter production theory and plot scale validation. Ecol Model 151:143-176. https:/doi.org/10.1016/ S0304-3800(01)00473-2

Jandl R, Lindner M, Vesterdal L, Bauwens B, Baritz R, Hagedorn F, Johnson DW, Minkkinen K, Byrne KA (2007) How strongly can forest management influence soil carbon sequestration? Geoderma 137:253-268. https://doi.org/ 10.1016/j.geoderma.2006.09.003

Jenkins JC, Chojnacky DC, Heath LS, Birdsey RA (2003) National-scale biomass estimators for United States tree species. For Sci 49(1):12-35. https://doi.org/ 10.1093/forestscience/49.1.12

Ji YH, Guo K, Ni J, Xu XN, Wang ZG, Wang SG (2016) Current forest carbon stocks and carbon sequestration potential in Anhui Province, China. Chinese J Plant Ecol 40:395-404 (in Chinese with English abstract)

Jia SW (2016) Study on carbon storage of forest vegetation and its economic value in Henan Province based on continuous forest resources inventory. Hubei Agric Sci 55:1612-1616 (in Chinese with English abstract)

Jin F, Yang H, Zhao QG (2000) Advances in research on soil organic carbon storage and its influencing factors. Soils 1:12-18

Ju WM, Chen JM, Harvey D, Wang SQ (2007) Future carbon balance of China's forests under climate change and increasing $\mathrm{CO}_{2}$. J Environ Manag 85:538562. https://doi.org/10.1016/j.jenvman.2006.04.028

Köhl M, Neupane PR, Lotfiomran N (2017) The impact of tree age on biomass growth and carbon accumulation capacity: a retrospective analysis using tree ring data of three tropical tree species grown in natural forests of Suriname. PLoS One 12(8):e0181187. https://doi.org/10. 1371/journal.pone. 0181187

Krankina O, Harmon M, Winjum J (1996) Carbon storage and sequestration in the Russian forest sector. Ambio 25:284-289

Kuuluvainen T, Gauthier S (2018) Young and old forest in the boreal: critical stages of ecosystem dynamics and management under global change. For Ecosyst 5:26. https://doi.org/10.1186/s40663-018-0142-2

Lafleur B, Fenton NJ, Simard M, Leduc A, Paré D, Valeria O, Bergeron Y (2018) Ecosystem management in paludified boreal forests: enhancing wood production, biodiversity, and carbon sequestration at the landscape level. For Ecosyst 5:27. https://doi.org/10.1186/s40663-018-0145-z

Lal R (2005) Forest soils and carbon sequestration. Forest Ecol Manag 220:242258. https://doi.org/10.1016/j.foreco.2005.08.015

Lamlom SH, Savidge RA (2003) A reassessment of carbon content in wood: variation within and between 41 North American species. Biomass Bioenergy 25:381-388. https://doi.org/10.1016/50961-9534(03)00033-3

Lamlom SH, Savidge RA (2006) Carbon content variation in boles of mature sugar maple and giant sequoia. Tree Physiol 26:459-468. https://doi.org/10. 1093/treephys/26.4.459

Ledermann T, Neumann M (2006) Biomass equations from data of old long-term experimental plots. Aust J For Sci 123(1):47-64

Lee J, Yoon TK, Han S, Kim S, Yi MJ, Park GS, Kim C, Son YM, Kim R, Son Y (2014) Estimating the carbon dynamics of South Korean forests from 1954 to 2012. Biogeosciences 11:4637-4650. https://doi.org/10.5194/bg-11-4637-2014

Li HK, Lei YC, Zeng WS (2011) Forest carbon storage in China estimated using forestry inventory data. Scientia Silvae Sinicae 47:7-12 (in Chinese with English abstract)

Li KR, Wang SQ, Cao MK (2003) Chinese vegetation and soil carbon storage. Chin Sci S D: Earth Sci 33:72-80
Liu F, Tan C, Zhang G, Liu JX (2013) Single-wood parameters and biomass airborne LiDAR estimation of Larix olgensis. Trans Chin Soc Agric Mach 44(9): 219-224, 242 (in Chinese with English abstract)

Liu GH, Fu BJ, Fang JY (2000) Carbon dynamics of Chinese forests and its contribution to global carbon balance. Acta Ecol Sin 20:733-740 (in Chinese with English abstract)

Liu J, Chen JM, Cihlar J, Park WM (1997) A process-based boreal ecosystem productivity simulator using remote sensing imputs. Remote Sens Environ 62:158-175. https://doi.org/10.1016/50034-4257(97)00089-8

Liu SN, Zhou T, Wei LY, Shu Y (2012) The spatial distribution of forest carbon sinks and sources in China. Chin Sci Bull 57(14):1699-1707. https://doi.org/10. 1007/s11434-012-4998-1

Liu X, Liu X, Skidmore A, Garcia C (2017) Recovery of woody plant species richness in secondary forests in China: a meta-analysis. Sci Rep 7:10614. https://doi.org/10.1038/s41598-017-10898-7

Liu Y, Yu G, Wang Q, Zhang Y (2014) How temperature, precipitation and stand age control the biomass carbon density of global mature forests. Glob Ecol Biogeogr 23:323-333. https://doi.org/10.1111/geb.12113

Lu F, Hu H, Sun W, Zhu J, Liu G, Zhou W, Zhang Q, Shi P, Liu X, Wu X, Lu Z, Wei X, Dai L, Zhang K, Sun Y, Xue S, Zhang W, Xiong D, Deng L, Liu B, Zhou L, Zhang C, Zheng X, Cao J, Huang Y, He N, Zhou G, Bai Y, Xie Z, Tang Z, Wu B, Fang J, Liu G, Yu G (2018) Effects of national ecological restoration projects on carbon sequestration in China from 2001 to 2010. Proc Natl Acad Sci 115(16):4039-4044

Ma S, He F, Tian D, Zou D, Yan Z, Yang Y, Zhou T, Huang K, Shen H, Fang J (2018) Variations and determinants of carbon content in plants: a global synthesis. Biogeosciences 15(3):693-702. https://doi.org/10.5194/bg-15-693-2018

MacPeak MD, Burkart LF, Weldon D (1990) Comparison of grade, yield, and mechanical properties of lumber produced from young fast-grown and old slow-grown planted slash pine. Forest Prod J 40(1):11-14

Nan J (2001) Carbon storage in terrestrial ecosystems of China: estimates at different spatial resolutions and their responses to climate change. Clim Chang 49:339-358

Nelson RF, Hyde P, Johnson P, Emessiene B, Imhoff ML, Campbell R, Edwards W (2007) Investigating RaDAR-LiDAR synergy in a North Carolina pine forest. Remote Sens Environ 110:98-108. https://doi.org/10.1016/j.rse.2007.02.006

Neumann M, Moreno A, Mues V, Härkönen S, Mura M, Bouriaud O, Lang M, Achten WMJ, Thivolle-Cazat A, Bronisz K, Merganič J, Decuyper M, Alberdi I, Astrup R, Mohren F, Hasenauer H (2016) Comparison of carbon estimation methods for European forests. Forest Ecol Manag 361:397-420. https://doi. org/10.1016/j.foreco.2015.11.016

O'Rourke SM, Angers DA, Holden NM, McBratney AB (2015) Soil organic carbon across scales. Glob Chang Biol 21:3561-3574. https://doi.org/10.1111/gcb.12959

Pan Y, Birdsey RA, Fang J, Houghton R, Kauppi PE, Kurz WA, Phillips OL, Shvidenko A, Lewis SL, Canadell JG, Ciais P, Jackson RB, Pacala S, McGuire AD, Piao S, Rautiainen A, Sitch S, Hayes D (2011) A large and persistent carbon sink in the world's forests. Science 333(6045):988 -993. https://doi. org/10.1126/science.1201609

Pan Y, Luo T, Birdsey R, Hom J, Melillo J (2004) New estimates of carbon storage and sequestration in China's forest: effects of age-class and method on inventory-based estimation. Clim Chang 67:211-236. https://doi.org/10.1007/ s10584-004-2799-5

Piao S, Fang J, Ciais P, Peylin P, Huang Y, Sitch S, Wang T (2009) The carbon balance of terrestrial ecosystems in China. Nature 458:1009-1013. https://doi. org/10.1038/nature07944

Piao S, Fang J, Zhou L, Zhu B, Tan K, Tao S (2005a) Changes in vegetation net primary productivity from 1982 to 1999 in China. Global Biogeochem Cy 19: 1-16. https://doi.org/10.1029/2004GB002274

Piao SL, Fang JY, Zhu B, Tan K (2005b) Forest biomass carbon stocks in China over the past 2 decades: estimation based on integrated inventory and satellite data. J Geophys Res 110:G01006. https://doi.org/10.1029/ 2005JG000014

Pietsch SA, Hasenauer H (2002) Using mechanistic modeling within forest ecosystem restoration. Forest Ecol Manag 159:111-131. https://doi.org/10. 1016/S0378-1127(01)00714-9

Poorter H, Niklas KJ, Reich PB, Oleksyn J, Poot P, Mommer L (2012) Biomass allocation to leaves, stems and roots: meta-analyses of interspecific variation and environmental control. New Phytol 193(1):30-50. https://doi.org/10.1111/ j.1469-8137.2011.03952.x

Post WM, Mann LK (1990) Changes in soil organic carbon and nitrogen as a result of cultivation. Soils and the greenhouse effect. Wiley, pp 410-416. https://doi.org/10.3334/CDIAC/tcm.006 
Repola J (2006) Models for vertical wood density of scots Pine, Norway spruce and birch stems, and their application to determine average wood density. Silva Fenn 40(4):673-685. https://doi.org/10.14214/sf.322

Rodríquez Martín JA, Álvaro-Fuentes J, Gonzalo J, Gil C, Ramos-Miras JJ, Grau Corbí JM, Boluda R (2016) Assessment of the soil organic carbon stock in Spain. Geoderma 264:117-125. https://doi.org/10.1016/j.geoderma.2015.10.010

Sage LK, Smith CT, Kurz W, Thiffault E, Paré D, Bernier P (2019) Empirical and predicted boreal forest carbon pools following stem-only harvesting in Quebec, Canada. Soil Sci Soc Am J. https://doi.org/10.2136/sssaj2018.07.0283

Shaban S (2011) Non-parametric forest attributes estimation using LiDAR and TM data. In: Paper presented at 32nd Asian Conference on Remote Sensing, pp 887-893

Smith JE, Heath LS, Jenkins JC (2002) Forest tree volume to biomass models and estimates for live and standing dead trees of U.S. forest. USDA Forest Service, Gen Tech Rep NE-298, p 57

Sun QF, Jia LM, Liu YL, Han LD, Liu BF (2016) Research progress of forest vegetation and soil carbon storage in China. Environ Chem 35:1741-1744 (in Chinese)

Tang X, Zhao X, Bai Y, Tang Z, Wang W, Zhao Y, Wan H, Xie Z, Shi X, Wu B, Wang G, Yan J, Ma K, Du S, Li S, Han S, Ma Y, Hu H, He N, Yang Y, Han W, He H, Yu G, Fang J, Zhou G (2018) Carbon pools in China's terrestrial ecosystems: new estimates based on an intensive field survey. PNAS 115:4021-4026. https:// doi.org/10.1073/pnas.1700291115

Tashi S, Singh B, Keitel C, Adams M (2016) Soil carbon and nitrogen stocks in forests along an altitudinal gradient in the eastern Himalayas and a meta-analysis of global data. Glob Chang Biol 22:2255-2268. https://doi.org/10.1111/gcb.13234

Thomas SC, Martin AR (2012) Carbon content of tree tissues: a synthesis. Forests 3:332-352. https://doi.org/10.3390/\$3020332

Thomas V, Treitz P, McCaughey JH, Morrison I (2006) Mapping stand-level forest biophysical variables for a mixedwood boreal forest using lidar: an examination of scanning density. Can J For Res 36:34-47. https:/doi.org/10.1139/x05-230

Tian H, Lu C, Yang J, Banger K, Huntzinger DN, Schwalm CR, Michalak AM, Cook R, Ciais P, Hayes D, Huang M, Ito A, Jain AK, Lei H, Mao J, Pan S, Post WM, Peng S, Poulter B, Ren W, Ricciuto D, Schaefer K, Shi X, Tao B, Wang W, Wei Y, Yang Q, Zhang B, Zeng N (2015) Global patterns and controls of soil organic carbon dynamics as simulated by multiple terrestrial biosphere models: current status and future directions. Global Biogeochem Cy 29:775792. https://doi.org/10.1002/2014GB005021

Tian H, Melillo J, Lu C, Kicklighter D, Liu M, Ren W, Xu X, Chen G, Zhang C, Pan S, Liu J, Running $S$ (2011) China's terrestrial carbon balance: contributions from multiple global change factors. Global Biogeochem Cy 25:1-16. https://doi. org/10.1029/2010gb003838

Toan TL, Beaudoin A, Riom J, Guyon D (1992) Relating forest biomass to SAR data. IEEE T Geosci Remote 30:403-411. https://doi.org/10.1109/36.134089

Van Groenigen KJ, Qi X, Osenberg CW, Luo Y, Hungate BA (2014) Faster decomposition under increased atmospheric $\mathrm{CO}_{2}$ limits soil carbon storage. Science 344:508-509. https://doi.org/10.1126/science.1249534

Vanguelova El, Bonifacio E, De Vos B, Hoosbeek MR, Berger TW, Vesterdal L, Armolaitis K, Celi L, Dinca L, Kjonaas OJ, Pavlenda P, Pumpanen J, Puttsepp U, Reidy B, Simoncic P, Tobin B, Zhiyanski M (2016) Sources of errors and uncertainties in the assessment of forest soil carbon stocks at different scales-review and recommendations. Environ Monit Assess 188:630. https:// doi.org/10.1007/s10661-016-5608-5

Wang P (2009) Forest carbon cycle model: a review. Chinese J Appl Ecol 20(6): 1505-1010 (in Chinese with English abstract)

Wang S, Huang M, Shao X, Mickler RA, Li K, Ji J (2004) Vertical distribution of soil organic carbon in China. Environ Manag 33(sup1):S200-S209. https://doi.org/ 10.1007/s00267-003-9130-5

Wang XK, Feng ZW, Ouyang ZY (2001) Vegetation carbon storage and density of forest ecosystems in China. Chinese J Appl Ecol 12:13-16 (in Chinese with English abstract)

Wang XK, Zhuang YH, Feng ZW (1994) Carbon dioxide release due to change in land use in China mainland. J Environ Sci 16:287-295

Warnant P, Francois L, Strivay D, Gerard JC (1994) CARAIB: a global model of terrestrial biological productivity. Global Biogeochem Cy 8:255-270. https:// doi.org/10.1029/94GB00850

Wen D, He NP (2016) Spatial patterns of litter density and their controlling factors in forests and grasslands of China. Acta Ecol Sin 36:2876-2884 (in Chinese with English abstract)

Wieder WR, Cleveland CC, Smith WK, Todd-Brown K (2015) Future productivity and carbon storage limited by terrestrial nutrient availability. Nat Geosci 8 : 441-444. https://doi.org/10.1038/ngeo2413
Wu QB, Wang XK, Duan XN, Deng LB, Lu F, Ouyang ZY, Feng ZW (2008) Carbon sequestration and its potential by forest ecosystems in China. Acta Ecol Sin 28:517-525 (in Chinese with English abstract)

Wulder MA, White JC, Nelson RF, Næsset E, Ørka HO, Coops NC, Hilker T, Bater CW, Gobakken T (2012) Lidar sampling for large-area forest characterization: a review. Remote Sens Environ 121:196-209. https://doi.org/10.1016/j.rse. 2012.02.001

Xie XL, Sun B, Zhou HZ, Li ZP (2004) Soil carbon stocks and their influencing factors under native vegetations in China. Acta Ped Sin 41:687-699 (in Chinese with English abstract)

Xie Z, Zhu J, Liu G, Cadisch G, Hasegawa T, Chen C, Sun H, Tang H, Zeng Q (2007) Soil organic carbon stocks in China and changes from 1980s to 2000s. Glob Chang Biol 13:1989-2007. https://doi.org/10.1111/j.1365-2486.2007.01409.x

Xing SL, Zhang GL, Liu HT, Wang DB (2004) Larch forest biomass estimation model based on Landsat ETM data. J Fujian Coll Forest 2:153-156 (in Chinese with English abstract)

Xu L, He NP, Yu GR, Wen D, Gao Y, He HL (2015) Differences in pedotransfer functions of bulk density lead to high uncertainty in soil organic carbon estimation at regional scales: evidence from Chinese terrestrial ecosystems. JGR: Biogeosciences 120:1567-1575. https://doi.org/10.1002/2015JG002929

Xu L, Yu G, He N, Wang Q, Gao Y, Wen D, Li S, Niu S, Ge J (2018) Carbon storage in China's terrestrial ecosystems: a synthesis. Sci Rep 8:2806. https://doi.org/ 10.1038/s41598-018-20764-9

Xu SS (2014) A review of forest carbon storage estimation methods. Forest Invent Plan 39:28-33 (in Chinese with English abstract)

Xu WM, Chen YF, Chen MH, Zheng LD, Zhang QL (2012) Research on the estimation of Chinese fir volume based on BP neural networks. J Fujian Coll Forest 32:310-315 (in Chinese with English abstract)

Xu XL, Cao MK, Li KR (2007) Temporal- spatial dynamics of carbon storage of forest vegetation in China. Prog Geogr 26:1-10 (in Chinese with English abstract)

Yang XF, Lu SW, Rao LY, Geng SB, Cao XX, Gao D (2011) Advances in the researches of carbon storage of forest ecology and related factors in China. J Northwest Forestry Univ 26:73-78 (in Chinese with English abstract)

Yang Y, Li P, Ding J, Zhao X, Ma W, Ji C, Fang J (2014) Increased topsoil carbon stock across China's forests. Glob Chang Biol 20:2687-2696. https://doi.org/ 10.1111/gcb.12536

Yang Y, Mohammat A, Feng J, Zhou R, Fang J (2007) Storage, patterns and environmental controls of soil organic carbon in China. Biogeochemistry 84: 131-141. https://doi.org/10.1007/s10533-007-9109-z

Yu GY, Wang XR, Li SG (2010) Carbon storage and its spatial pattern of terrestrial ecosystem in China. J Resour Ecol 1:97-109. https://doi.org/10.3969/j.issn. 1674-764x.2010.02.001

Zeng W (2014) Development of monitoring and assessment of forest biomass and carbon storage in China. For Ecosyst 1:20. https://doi.org/10.1186/ s40663-014-0020-5

Zhang C, Ju W, Chen J, Zan M, Li D, Zhou Y, Wang X (2013a) China's forest biomass carbon sink based on seven inventories from 1973 to 2008. Clim Chang 118:933-948. https://doi.org/10.1007/s10584-012-0666-3

Zhang C, Peng DL, Tu YY, Dang YF, Zhi CG (2013b) Predicting forest volume in Three Gorges Reservoir Region using TM images and partial least squares regression. J Beijing Forest Univ 35:11-17 (in Chinese with English abstract)

Zhang CH, Ju WM, Chen JM, Wang XQ, Yang L, Zheng G (2015) Disturbanceinduced reduction of biomass carbon sinks of China's forests in recent years. Environ Res Lett 10:114021. https://doi.org/10.1088/1748-9326/10/11/114021

Zhang H, Liu Q, Lu P, Yu Q (2005) Overview of the carbon cycle model of terrestrial ecosystems. China Sci Tech Infor 13:25-26 (in Chinese)

Zhao M, Yang J, Zhao N, Liu Y, Wang Y, Wilson JP, Yue T (2019) Estimation of China's forest stand biomass carbon sequestration based on the continuous biomass expansion factor model and seven forest inventories from 1977 to 2013. Forest Ecol Manag 448:528-534. https://doi.org/10.1016/j.foreco.2019.06.036

Zhao M, Zhou GS (2004) Carbon storage of forest vegetation and its relationship with climatic factors. Sci Geogr Sin 1:50-54 (in Chinese with English abstract)

Zhao MW, Yue TX, Zhao N, Sun XF (2013) Spatial distribution of forest vegetation carbon stock in China based on HASM. Acta Geograph Sin 68:1212-1224 (in Chinese with English abstract)

Zhao XZ (2012) Soil organic carbon pool and its turnover in main forest community types in Xiaoxing'an Mountains. Doctor, Northeast Forestry University (in Chinese with English abstract)

Zheng J, Zeng H, Zhong X (2005) Remaining cedar planting business model C library and its distribution. J Fujian Normal Univ (Natural Science Edition) 3: 65-69 (in Chinese with English abstract) 
Zhou YR, Yu ZL, Zhao SD (2000) Carbon storage and budget of major Chinese forest types. Chinese J Plant Ecol 24:518-522 (in Chinese with English abstract)

Zhu J, Hu H, Tao S, Chi X, Li P, Jiang L, Ji C, Zhu J, Tang Z, Pan Y, Birdsey RA, He X, Fang J (2017) Carbon stocks and changes of dead organic matter in China's forests. Nat Commun 8:151. https://doi.org/10.1038/s41467-017-00207-1

Zhu X, Liu D (2015) Improving forest aboveground biomass estimation using seasonal Landsat NDVI time-series. ISPRS J Photogramm 102:222-231. https:// doi.org/10.1016/j.isprsjprs.2014.08.014

Submit your manuscript to a SpringerOpen ${ }^{\mathcal{O}}$ journal and benefit from:

- Convenient online submission

- Rigorous peer review

- Open access: articles freely available online

- High visibility within the field

- Retaining the copyright to your article

Submit your next manuscript at $\boldsymbol{\nabla}$ springeropen.com 